\title{
Response of Roselle Plants (Hibiscus sabdariffa l.) to Pressed Olive Cake Compost Types and Potassium Fertilization Rates on Newly Reclaimed Soils at Siwa Oasis, Egypt \\ Khatab, A. Kh. \\ Soils, Water and Environment Research Institute, Agricultural Research Center, Giza, Egypt
}

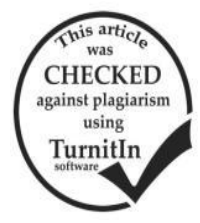

\section{ABSTRACT}

This investigation was carried out during the two seasons of 2013 and 2014 at the experimental farm of Matrouh Agricultural Research Station, Siwa Oasis, Matrouh Governorate, Egypt, (29.11 ${ }^{\circ} \mathrm{N}$ latitude and $25.33^{\circ}$ E longitude). The study aiming at evaluating the effect of two types of composts pressed olive cake (POC) and POC+CM (chicken manure) combined potassium fertilizer levels and their interactions on yield, yield components and some sepals chemical constituents of Rosella plants. The obtained results could be summarized as follows:- $*$ The investigated compost types exerted significant effects on plant height, branches No. plant ${ }^{-1}$, seed yield $\left(\mathrm{g} \mathrm{plant}^{-1}\right)$ and seed yield $\left(\mathrm{kg} \mathrm{fed}^{-1}\right)$ of Roselle plants, and POC+CM compost exhibited the highest figures in $1^{\text {st }}$ and $2^{\text {nd }}$ seasons. The adopted $\mathrm{K}$ fertilization rates significantly affected the abovementioned parameters, which gradually increased due to increasing $\mathrm{k}$ fertilization ratefigures in the $1^{\text {st }}$ and $2^{\text {nd }}$ seasons. All the parameters were significantly influenced due to the interaction and the highest values were recorded under POC+CM compost and $48 \mathrm{~kg}$ $\mathrm{K}_{2} \mathrm{Ofed}^{-1}$ rate interaction in $1^{\text {st }}$ and $2^{\text {nd }}$ seasons. *Sepals yield and its components of Roselle plants were significantly influenced due to the tested compost types and $\mathrm{K}$ fertilization rates and interaction in $1^{\text {st }}$ and $2^{\text {nd }}$ seasons. Both POC+CM compost and $48 \mathrm{~kg}$ $\mathrm{K}_{2} \mathrm{O}$ fed ${ }^{-1}$ rate exhibited the highest figures of the abovementioned parameters $1^{\text {st }}$ and $2^{\text {nd }}$ seasons. The highest values of sepals yield and its components were attained due to POC+CM compost as interacted with $48 \mathrm{~kg} \mathrm{~K}_{2} \mathrm{Ofed}^{-1} \mathrm{rate}_{\text {in }} 1^{\text {st }}$ and $2^{\text {nd }}$ seasons. ${ }^{*} \mathrm{~N}, \mathrm{P}$ and $\mathrm{K} \%$ of roselle petals were significantly influenced due to the investigated compost types and $\mathrm{K}$ fertilization rates. The highest $\mathrm{N}, \mathrm{P}$ and $\mathrm{K}$ figures were attained with both $\mathrm{POC}+\mathrm{CM}$ compost and $48 \mathrm{~kg} \mathrm{~K}_{2} \mathrm{O}$ fed $^{-1}$ rate $1^{\text {st }}$ and $2^{\text {nd }}$ seasons. In addition, interaction of POC+CM compost and $48 \mathrm{~kg} \mathrm{~K}_{2} \mathrm{O}$ fed $^{-1}$ rate exhibited the highest values, however, the differences did not reach the significance level, and such trend was true in $1^{\text {st }}$ and $2^{\text {nd }}$ seasons. * Chemical constituents of roselle sepals e.g. total carbohydrates, anthocyanin ascorbic acid contents and $\mathrm{pH}$ were significantly influenced due to $\mathrm{K}$ fertilization rates, whereas

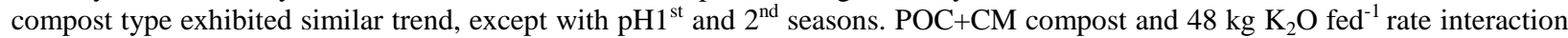
still exhibiting the highest values of the abovementioned parameters, however, the differences did not reach the significance level, and such trend was true in $1^{\text {st }}$ and $2^{\text {nd }}$ seasons. On conclusion, supplying POC compost combined with $48 \mathrm{~kg} \mathrm{~K}_{2} \mathrm{O}$ fed ${ }^{-1}$ resulted in higher values of sepals yield and quality and macronutrients uptake as well, however, it is advisable to replace POC compost by POC compost +CM which absolutely exhibited the highest values of the studied parameters under the present experimental conditions.

Keywords: Rosella plants (Hibiscus sabdariffa L.), growth, productivity, chemical constituents, pressed olive cake compost, potassium fertilization

\section{INTRODUTION}

Medicinal plants are valuable resources in a wide range of natural resources that occupied a prominent economic position because of the continuous increasing demand for these plants for the local and foreign markets. Among these medicinal rosella plants (Hibiscus sabdariffa L.) which is belonging to the family Malvaceae and has a common name in Egypt as Karkadeh. Roselle plants are cultivated mainly for the important commercial part of the plant which is the fleshy sepals (calyx) surrounding the fruit (capsules). This plant can grow on a wide range of soil conditions, but for economic with production, soil should be well supplied essential minerals, which can improve sepals yield and quality. Nitrogen and potassium are two major limiting nutrients for plant growth and yield (Adanlawo and Ajibade, 2006). So, great attention to cultive such plants and exporting the calyx can be an important economic issue.

At Siwa oasis, large quantities of pressed olive cake are resulted as a waste of olive oil extraction. Moreover, increasing the organic matter content of soil (especially in newly reclaimed soils) has the additional benefits of mitigating the problems associated with the use of brackish or saline waters which are frequently used in these areas for crop irrigation, Tomar et al.,(2003).

Many authors documented the favorable effects of pressed olive cake compost on sandy soils such as increasing nutrient availability, cation exchange capacity, organic matter content and enzymes activity which consequently stimulates plant growth and plant productivity, Cucci et al.(2008). In addition, Giovanna et al. (2008) showed that supplying wet olive pomace improved soil structure, increased organic matter and nutrient content without altering $\mathrm{pH}$ and salinity. Moreover, it improved nutrient content in sunflower and wheat in comparison with the control. Furthermore, Montemurro et al., (2004) showed that addition of olive pomace compost increased growth, yield and macronutrients (NPK) uptake as well as dry matter content of rye-grass.

In Egypt ,El-Tantawy and Mohamed (2009) under Sinai conditions found that, addition of pressed olive cake composting with chicken manure and phosphate solubilizing bacteria enhanced tomato plant growth, number and weight of fruits and increased phosphorus content in leaves. In connection, Ben-Jenana et al. (2009) found that addition of olive husks compost with pozidonia and chicken manure significantly improved growth characters and yield of tomato plants. Sellami et al. (2007) and Hachicha et al. (2006) reported that addition the compost of olive husks with chicken manure and irrigated with olive mill wastewater improved soil properties, did not have any negative impact on soil phenols, $\mathrm{pH}$ and EC at different soil depths and enhanced a better growth and yield of potato.

Unfortunately, the literatures interesting the response of Roselle plants to olive cake compost addition 
are not available. However, tremendous literatures concerning the effect of other types of organic compost wastes on Roselle growth are cited such as Abou-ElSeoud et al. (1997); El-Keltawi et al. (2003); El-Sherif and Sarwat (2007) and Yasser et al. (2011) who reported that application of organic manure to Roselle increased vegetative growth parameters, number of branches and fruits, sepal yield and a slight increase in the protein and phosphorus content of sepals of Roselle.

It is well known that potassium regulates many metabolic processes in plants. It is involved in cell division and enlargement, increases stress tolerance, regulates the opening and closing of the stomata and it is required for osmotic regulation. In addition, $\mathrm{K}$ promotes photosynthesis and activates enzymes and coenzymes to metabolize carbohydrates for the manufacture of starch and protein. Furthermore, potassium improves oil content in oil crops and is essential for the development of the root system Bidari and Hebsur (2011). In connection, Shalan et al.(2001) investigated the effect of nitrobein (biofertilizer), nitrogen fertilizer; (40 or $60 \mathrm{~kg} \mathrm{~N} / \mathrm{fed}$ ) combined with potassin as foliage spray or potassium sulfate; (50 or $100 \mathrm{~kg} / \mathrm{fed}$.) on Roselle plants and reported that $\mathrm{N}$ and $\mathrm{K}$ at different levels increased plant height, number of branches, number of fruit/plant, sepal weight (fresh \& dry), anthocyanin, sugars and protein contents of sepals. The author added that Potassin (foliar P K fertilizer) as a source of potassium resulted in a high significant increases in most parameters; branch number, fruit number/plant, acidity, as well as anthocyanin, sugars and protein contents.

The main objective of this study is to find out whether sufficient and high quality of roselle yield can be produced using pressed olive cake compost, pressed olive cake + chicken manure compost and potassium fertilization under the soil and climate conditions of Siwa Oasis.

\section{MATERIALS AND METHODS}

A field experiment was conducted in a newly reclaimed soil at the experimental farm at Siwa Oasis located at $29.11^{\circ} \mathrm{N}$ latitude and $25.33^{\circ} \mathrm{E}$ longitude, Matrouh Agricultural Research Station, Agricultural Research Center (ARC), Egypt, during 2013 and 2014 growing seasons. aiming to evaluate compost type e.g. pressed olive cake (POC) and pressed olive cake (POC)+Chicken Manure (CM) in 1:1 ratio, both at rate of 2 tonfed $^{-1}$ under potassium fertilization rates of 0,24 and $48 \mathrm{~kg} \mathrm{~K}_{2} \mathrm{O} \mathrm{fed}{ }^{-1}$ on growth, sepals yield and its components and chemical constitutes of Roselle (Hibiscus Sabdariffa L.) as well.

Particle size distribution and some chemical characteristics of the experimental soil as determined according to Ryan et al. (1996) are shown in Table 1.

The POC accumulates, in huge quantities, as a waste from olive oil mills at Siwa Oasis. The POC used in the present study was obtained from the olive oil extraction mill belongs to Desert Research Center (DRC) at Siwa Oasis, whereas CM was collected from the local peoples. On preparing the compost piles of POC and POC+CM ( $2 \mathrm{~m}^{3}$ in volume $)$ were prepared and insulated for 3- month period. During the composting process both windrows were homogenized by mixing every two weeks and moistened to keep the moisture in the range of 40 to $60 \%$. The piles were periodically sampled at zero, 30, 60 and 120 days for chemical analyses to determine percentages of $\mathrm{N}, \mathrm{P}, \mathrm{K}$ and organic carbon, and data are represented in Table 2.

Table 1: Soil particle size distribution and some chemical characteristics of the experimental site, 2013 and 2014 seasons.

\begin{tabular}{|c|c|c|c|}
\hline properties & & 2013 season & 2014 season \\
\hline \multirow{4}{*}{ Particle size distribution (\%) } & Coarse sand & 7.40 & 8.70 \\
\hline & Fine sand & 61.20 & 64.80 \\
\hline & Silt & 26.60 & 22.40 \\
\hline & Clay & 4.80 & 4.10 \\
\hline Textural class & & Sandy loam & Sandy loam \\
\hline $\mathrm{EC} \mathrm{dSm}^{-1}$ (soil paste extract) & & 2.41 & 2.23 \\
\hline $\mathrm{pH}(1: 2.5$, soil: water suspension $)$ & & 7.42 & 7.28 \\
\hline \multirow[t]{2}{*}{$\mathrm{CaCO}_{3}(\%)$} & & 6.20 & 5.80 \\
\hline & $\mathrm{Ca}^{+2}$ & 5.14 & 4.92 \\
\hline \multirow{3}{*}{ Soluble cations (meqL ${ }^{-1)}$} & $\mathrm{Mg}^{+2}$ & 4.32 & 4.24 \\
\hline & $\mathrm{Na}^{+}$ & 13.74 & 12.42 \\
\hline & $\mathrm{K}^{+}$ & 1.58 & 1.42 \\
\hline \multirow{4}{*}{ Soluble anions $\left(\mathrm{meqL}^{-1}\right)$} & $\mathrm{HCo}_{3}{ }^{-}$ & 5.34 & 4.87 \\
\hline & $\mathrm{Cl}^{-}$ & 9.00 & 8.75 \\
\hline & $\mathrm{SO}_{4}^{--}$ & 10.44 & 9.38 \\
\hline & $\mathrm{N}$ & 11.22 & 11.72 \\
\hline \multirow[t]{2}{*}{ Available nutrients (ppm) } & $\mathrm{P}$ & 3.42 & 3.86 \\
\hline & $\mathrm{K}$ & 22.85 & 24.15 \\
\hline
\end{tabular}

\section{Experimental design and execution}

The experiment was laid out in a split-plot design with three replicates. The main plots were assigned for compost types e.g. control (without compost addition),
POC and POC+CM both at 2 ton $\mathrm{fed}^{-1}$ rate, whereas the subplots were devoted to potassium fertilization rates e.g. control (without $\mathrm{K}$ fertilization), 24 and $48 \mathrm{~kg} \mathrm{~K} \mathrm{~K}_{2} \mathrm{O}$ $\mathrm{fed}^{-1}$ in potassium sulphate form. The experimental unit 
area was $14 \mathrm{~m}^{2}(3.5 \mathrm{mx} 4.00 \mathrm{~m})$ contained five ridges 70 $\mathrm{cm}$ apart and $50 \mathrm{~cm}$ between plants i.e. 40 plants per plot. Seeds of Roselle (Hibiscus sabdariffa L., cv. Sabaheia 17) were obtained from Medicinal and Aromatic Plants Research Department, Horticulture Research Institute, Agricultural Research Center, Giza. Four seeds per hill were sown on $6^{\text {th }}$ and $2^{\text {nd }}$ April in the $1^{\text {st }}$ and $2^{\text {nd }}$ seasons, respectively. After one month, the seedlings were thinned to leave one seedling per hill.
The tested composts, potassium fertilizer levels, and calcium superphosphate $\left(15 \% \quad \mathrm{P}_{2} \mathrm{O}_{5}\right.$ at rate of $30 \mathrm{~kg}$ $\mathrm{P}_{2} \mathrm{O}_{5} \mathrm{fed}^{-1}$ ) as well were applied during seedbed preparation. Nitrogen fertilizer as ammonium nitrate (33.5\%) was added at $40 \mathrm{~kg} \mathrm{Nfed}^{-1}$ rate divided into three equal portions at 35,50 and 70 days after planting. Surface drip irrigation was adopted in the experimental field, and chemical analyses of the irrigation water are shown in Table 3.

Table 2: Chemical analyses for POC and POC + CM piles at different periods during composting process in 2013 and 2014 seasons.

\begin{tabular}{|c|c|c|c|c|c|c|c|c|}
\hline \multirow{3}{*}{ Treatments } & \multicolumn{8}{|c|}{2013 season } \\
\hline & \multicolumn{4}{|c|}{ Pressed olive cake } & \multicolumn{4}{|c|}{ Pressed olive cake + chicken manure } \\
\hline & Initial time & 30 days & 60 days & 120 days & Initial time & 30 days & 60 days & 120 days \\
\hline Total N (\%) & 1.19 & 1.11 & 1.21 & 1.29 & 1.28 & 1.19 & 1.31 & 1.39 \\
\hline Total P (\%) & 0.15 & 0.11 & 0.17 & 0.18 & 0.17 & 0.14 & 0.17 & 0.19 \\
\hline Total K (\%) & 1.18 & 1.14 & 1.18 & 1.21 & 1.22 & 1.17 & 1.23 & 1.24 \\
\hline Organic matter $\%$ & 57.98 & 60.31 & 53.78 & 52.92 & 55.63 & 60.02 & 50.17 & 43.63 \\
\hline Organic carbon $\%$ & 33.63 & 34.98 & 31.19 & 30.70 & 32.27 & 34.86 & 29.10 & 25.31 \\
\hline \multirow[t]{2}{*}{ C/N Ratio } & 28.26 & 31.51 & 25.78 & 23.80 & 25.21 & 29.29 & 22.21 & 18.21 \\
\hline & \multicolumn{8}{|c|}{2014 season } \\
\hline Total N (\%) & 1.22 & 1.12 & 1.25 & 1.32 & 1.31 & 1.23 & 1.36 & 1.41 \\
\hline Total P (\%) & 0.17 & 0.15 & 0.20 & 0.25 & 0.20 & 0.18 & 0.19 & 0.23 \\
\hline (Total K (\% & 1.22 & 1.19 & 1.23 & 1.26 & 1.25 & 1.21 & 1.27 & 1.29 \\
\hline Organic matter $\%$ & 58.33 & 61.05 & 55.22 & 53.57 & 56.12 & 58.15 & 51.55 & 41.78 \\
\hline Organic carbon $\%$ & 33.83 & 35.41 & 32.03 & 31.07 & 32.55 & 34.86 & 29.90 & 24.23 \\
\hline $\mathrm{C} / \mathrm{N}$ ratio & 27.73 & 31.61 & 25.62 & 23.54 & 24.84 & 28.34 & 21.98 & 17.18 \\
\hline
\end{tabular}

Table 3: Chemical analyses of the irrigation water.

\begin{tabular}{|c|c|c|c|c|c|c|c|c|c|c|}
\hline \multirow[t]{2}{*}{ Season } & EC & & & & $\begin{array}{r}P a \\
\text { uble ca }\end{array}$ & $\begin{array}{l}\text { neters } \\
\text { is (mo }\end{array}$ & & Sol & anions & $\left(\mathbf{L}^{-1}\right)$ \\
\hline & $\left(\mathrm{dSm}^{-1}\right)$ & ppm & $\mathbf{p H}$ & $\mathrm{Na}^{+}$ & $\mathbf{M g}^{++}$ & $\mathrm{Ca}^{++}$ & $\mathbf{K}^{+}$ & $\mathrm{Cl}^{-}$ & $\mathrm{HCO}_{3}^{-}$ & $\mathrm{SO}_{4}=$ \\
\hline 2013 & 3.13 & 2003 & 7.6 & 10.8 & 2.9 & 3.4 & 0.2 & 9.2 & 3.2 & 4.9 \\
\hline 2014 & 2.35 & 1504 & 7.1 & 10.5 & 2.3 & 3.2 & 0.2 & 8.8 & 3.0 & 4.4 \\
\hline
\end{tabular}

Data Recorded:

At harvest time (200 days after sowing), the plants were sampled at random from the middle ridges of the experimental unit to estimate the following data:

Plant height $(\mathrm{cm})$, number of branches plant ${ }^{-1}$, number of fruits plant ${ }^{-1}$, fresh weigh of fruits plant $^{-1}$, dry weigh of sepal plant ${ }^{-1}(\mathrm{~g})$, seed yield plant ${ }^{-1}(\mathrm{~g})$, seed yield $\left(\mathrm{kgfed}^{-1}\right)$ and sepal yield $\left(\mathrm{kgfed}^{-1}\right)$, Concerning dry sepals chemical constituents, nitrogen content was determined by wet oxidation using Kjeldahl digestion and distillation procedures, Parkinson and Allen (1975), while phosphorous was determined calorimetrically according to the procedure outlined by (Ryan et al.1996). Potassium content was determined using flame photometer according to (Black, 1982).Total carbohydrate and ascorbic acid were determined according to Nielsen (2010), anthocyanin content was determined as described by Byamukama et al. (2014). Acidity of sepal was determined according to AOAC (1975). Data were subjected to the statistical analysis according to Snedecor and Cochran (1980). Mean values of the treatments were compared against each other using the least significant differences (LSD) at 5\% level of significance.

\section{RESULTS AND DISCUSSION}

1- Plant height, branches No. plant ${ }^{-1}$, seed yield(g plant $^{-1}$ ) and seed yield (kg fed ${ }^{-1}$ )

(a) Effect of compost types

Data presented in Table 4 show that the tested parameters were significantly affected due to the adopted compost types and $\mathrm{K}$ fertilization rates and interactions and $\mathrm{POC}+\mathrm{CM}$ compost exhibited the highest figures in the $1^{\text {st }}$ and $2^{\text {nd }}$ seasons.

The increases in plant height, number of branches plant $^{-1}$, seed yield $\left(\mathrm{g}\right.$ plant $\left.{ }^{-1}\right)$ and seed yield $\left(\mathrm{kg} \mathrm{fed}^{-}\right.$ ${ }^{1}$ ), due to POC+CM compost application, amounted to (48.21 and 57.88\%), (25.44 and 71.67\%),(82.34 and $25.86 \%)$ and $(84.26$ and $24.18 \%)$ in the $1^{\text {st }}$ season and by $(51.52$ and $57.12 \%)$, (23.77and $62.88 \%),(81.47$ and $24.14 \%$ ) and ( 82.72 and $24.95 \%)$ in the $2^{\text {nd }}$ one, respectively, compared to $\mathrm{POC}$ and the control. The beneficial effect of $\mathrm{POC}+\mathrm{CM}$ compost is attributed to providing the necessary the soil macro and micronutrients, in available forms, which are necessary for healthy plant growth. Such results are in accordance with those reported by Tomati et al., 1996; Cucci et al., 2008 and Medjahdi et al., 2014. 


\section{(b) Effect of potassium fertilization rates}

Respecting the effect of potassium fertilization on studied parameters of roselle plants, data in Table 4 reveal that increasing potassium rate from zero to 24 or

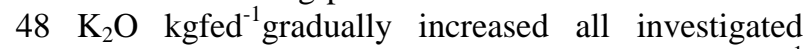
parameters. The increase values, under $48 \mathrm{~K}_{2} \mathrm{O} \mathrm{Kgfed}^{-1}$ rate, in plant height, number of branches plant ${ }^{-1}$, seed yield $\left(\right.$ gplant $\left.^{-1}\right)$ and seed yield $\left(\mathrm{kgfed}^{-1}\right)$ in $1^{\text {st }}$ season, amounted to (5.64 and 17.45\%), (19.54 and 71.59 $\%),(10.89$ and $29.25 \%)$ and ( 2.37 and $29.61 \%$ ) higher than those with $24 \mathrm{~K}_{2} \mathrm{O} \mathrm{kgfed}{ }^{-1}$ rate and the control, respectively. In $2^{\text {nd }}$ season, the corresponding increases for the abovementioned parameters reached to (15.49 and $25.58 \%),(18.63$ and $60.09 \%),(13.25$ and $30.15 \%)$ and $(13.83$ and $32.50 \%)$ in the same order of the treatments. Such increases are attributable to favorable effect of the highest $\mathrm{K}$ - fertilization rate in regulating many metabolic processes in Roselle plants. These results are in accordance with those reported by Abo-ElSeoud et al. (1994), Abbas and Ali (2011) and Sakr et al., (2014) on Roselle plants.

\section{(c) Effect of the interaction}

Regarding the effect of interacted factors under study on Plant height, Branches No. plant ${ }^{-1}$, Seed yield $\left(\mathrm{g}\right.$ plant $\left.{ }^{-1}\right)$ and Seed yield $\left(\mathrm{kg} \mathrm{fed}^{-1}\right)$ of Roselle plants, data illustrated that the combination of $\mathrm{POC}+\mathrm{CM}$ compost and the highest potassium fertilization rate resulted in the highest figures of the investigated parameters, Table 4.

Table 4: Plant height, branches No. plant ${ }^{-1}$, seed yield $\left(\mathrm{g} \mathrm{plant}^{-1}\right)$ and seed yield $\left(\mathrm{kg} \mathrm{fed}^{-1}\right)$ of roselle plants as affected by compost types and potassium fertilization rates and interaction 2013 and 2014 seasons

\begin{tabular}{|c|c|c|c|c|c|}
\hline \multirow[b]{2}{*}{ Treatments } & & \multicolumn{4}{|c|}{2013 Season } \\
\hline & & $\begin{array}{c}\text { Plant height } \\
(\mathrm{cm})\end{array}$ & $\begin{array}{c}\text { Branches No. } \\
\text { plant }^{-1}\end{array}$ & $\begin{array}{l}\text { Seed yield } \\
\left(\text { g plant }^{-1}\right)\end{array}$ & $\begin{array}{c}\text { Seed yield } \\
\left(\mathrm{kg} \mathrm{fed}^{-1}\right)\end{array}$ \\
\hline Control, zero compost & & 89.26 & 8.33 & 17.16 & 223.36 \\
\hline POC* & & 95.09 & 11.40 & 24.86 & 331.41 \\
\hline $\mathrm{POC}+\mathrm{CM}^{* *}$ & & 140.93 & 14.30 & 31.29 & 411.56 \\
\hline L.S.D at 0.05 & & 2.39 & 0.27 & 1.21 & 5.96 \\
\hline Control & & 98.98 & 8.20 & 21.20 & 277.71 \\
\hline $24 \mathrm{~kg} \mathrm{~K}_{2} \mathrm{O}$ & & 110.04 & 11.77 & 24.71 & 368.69 \\
\hline $48 \mathrm{~kg} \mathrm{~K}_{2} \mathrm{O}$ & & 116.25 & 14.07 & 27.40 & 359.94 \\
\hline L.S.D at 0.05 & & 2.07 & 0.18 & 1.07 & 12.01 \\
\hline \multirow{3}{*}{$\begin{array}{l}\text { Control, zero compost } \\
\text { addition }\end{array}$} & Zero $\mathrm{K}_{2} \mathrm{O}$ & 82.70 & 5.80 & 14.81 & 192.54 \\
\hline & $24 \mathrm{~kg} \mathrm{~K}_{2} \mathrm{O}$ & 90.85 & 8.60 & 17.27 & 224.68 \\
\hline & $48 \mathrm{~kg} \mathrm{~K}_{2} \mathrm{O}$ & 94.23 & 10.60 & 19.39 & 252.87 \\
\hline & Zero $\mathrm{K}_{2} \mathrm{O}$ & 87.55 & 7.60 & 21.14 & 279.48 \\
\hline \multirow[t]{3}{*}{ POC } & $24 \mathrm{~kg} \mathrm{~K}_{2} \mathrm{O}$ & 96.42 & 11.80 & 25.33 & 343.56 \\
\hline & $48 \mathrm{~kg} \mathrm{~K}_{2} \mathrm{O}$ & 101.30 & 14.80 & 28.12 & 371.18 \\
\hline & Zero $\mathrm{K}_{2} \mathrm{O}$ & 126.70 & 11.20 & 27.65 & 361.10 \\
\hline \multirow[t]{2}{*}{$\mathrm{POC}+\mathrm{CM}$} & $24 \mathrm{~kg} \mathrm{~K}_{2} \mathrm{O}$ & 142.85 & 14.90 & 31.52 & 417.82 \\
\hline & $48 \mathrm{~kg} \mathrm{~K}_{2} \mathrm{O}$ & 153.23 & 16.80 & 34.69 & 455.77 \\
\hline \multirow[t]{3}{*}{ L.S.D at 0.05} & & 3.11 & 0.43 & 1.64 & 8.88 \\
\hline & & \multicolumn{4}{|c|}{2014 Season } \\
\hline & & \multicolumn{4}{|c|}{ Compost types effect } \\
\hline \multicolumn{2}{|l|}{ Control, zero compost } & 97.91 & 9.08 & 18.24 & 239.59 \\
\hline \multicolumn{2}{|l|}{ POC* } & 101.53 & 22.95 & 26.64 & 350.37 \\
\hline \multicolumn{2}{|l|}{$\mathrm{POC}+\mathrm{CM} * *$} & 153.84 & 14.79 & 33.07 & 437.78 \\
\hline & 4.74 & 0.18 & 1.07 & 12.01 \\
\hline \multicolumn{2}{|l|}{ L.S.D at 0.05} & \multicolumn{4}{|c|}{$\mathrm{K}$ - fertilization rates effect } \\
\hline \multicolumn{2}{|l|}{ Control } & 105.67 & 9.07 & 22.59 & 294.57 \\
\hline \multicolumn{2}{|l|}{$24 \mathrm{~kg} \mathrm{~K}_{2} \mathrm{O}$} & 114.90 & 12.24 & 25.96 & 342.88 \\
\hline \multicolumn{2}{|l|}{$48 \mathrm{~kg} \mathrm{~K}_{2} \mathrm{O}$} & 132.70 & 14.52 & 29.40 & 390.31 \\
\hline \multicolumn{2}{|l|}{ L.S.D at 0.05} & 4.74 & 0.18 & 1.07 & 12.01 \\
\hline \multicolumn{6}{|c|}{ Interaction effect } \\
\hline \multirow{4}{*}{$\begin{array}{l}\text { Control, zero compost } \\
\text { addition }\end{array}$} & Zero $\mathrm{K}_{2} \mathrm{O}$ & 91.55 & 6.92 & 15.74 & 204.15 \\
\hline & $24 \mathrm{~kg} \mathrm{~K}_{2} \mathrm{O}$ & 97.85 & 9.10 & 17.98 & 237.85 \\
\hline & $48 \mathrm{~kg} \mathrm{~K}_{2} \mathrm{O}$ & 104.32 & 11.22 & 21.00 & 276.76 \\
\hline & Zero $\mathrm{K}_{2} \mathrm{O}$ & 94.60 & 8.43 & 23.05 & 302.42 \\
\hline \multirow[t]{3}{*}{ POC } & $24 \mathrm{~kg} \mathrm{~K}_{2} \mathrm{O}$ & 101.88 & 12.28 & 26.76 & 352.14 \\
\hline & $48 \mathrm{~kg} \mathrm{~K}_{2} \mathrm{O}$ & 108.12 & 15.15 & 30.11 & 396.55 \\
\hline & Zero $\mathrm{K}_{2} \mathrm{O}$ & 130.87 & 11.86 & 28.97 & 377.13 \\
\hline \multirow[t]{2}{*}{$\mathrm{POC}+\mathrm{CM}$} & $24 \mathrm{~kg} \mathrm{~K}_{2} \mathrm{O}$ & 144.98 & 15.33 & 33.15 & 438.58 \\
\hline & $48 \mathrm{~kg} \mathrm{~K}_{2} \mathrm{O}$ & 185.66 & 17.18 & 37.08 & 497.62 \\
\hline L.S.D at 0.05 & & 8.21 & 0.51 & 1.84 & 20.18 \\
\hline
\end{tabular}


2- Dry sepals yield and its components:

\section{(a) Effect of compost types}

Results in Table 5 show that the adopted compost types and $\mathrm{K}$ fertilization rates and interaction as well significantly affected sepals yield and its components of Roselle plants. Supplying POC+CM compost resulted in the highest figures of sepal yield per feddan which were higher by (63.04 and 17.96\%) and (59.04 and 14.01\%) than those under without compost addition and POC compost addition in $1^{\text {st }}$ and $2^{\text {nd }}$ seasons, respectively. Similar trends were noticed with dry weigh of sepals $\left(\right.$ gplant $^{-1}$ ), number of fruits plant ${ }^{-1}$ and fresh weigh of fruits $\left(\right.$ gplant $\left.^{-1}\right)$. The increase percentages, due to POC $+\mathrm{CM}$ compost addition, were (74, 00 and 13.88), (68.90 and 13.21) and (70.97 and 14.26) higher than those under without compost addition and POC compost addition, respectively, in $1^{\text {st }}$ season. The corresponding increase percentages in $2^{\text {nd }}$ season were (59.04 and 14.20), (67.83 and 14.03), (67.54 and 15.93) and (65.95 and 13.98) in the same order of treatments and parameters. Similar results have been obtained due to supplying compost from different organic wastes on Roselle plants, Abo-El-Seoud et al. (1997)، El-Sheriff and Sarwat (2007) and Yasser et al.(2011).

\section{(b) Effect of potassium fertilization rates}

The highest figures of the investigated parameters were recorded with $48 \mathrm{~kg} \mathrm{~K}_{2} \mathrm{Ofed}^{-1}$ rate and such trend was true in the $1^{\text {st }}$ and $2^{\text {nd }}$ seasons, Table 5 . In the $1^{\text {st }}$ season, reducing the $\mathrm{k}$ fertilization rate to be without $\mathrm{k}$ addition and $24 \mathrm{~kg} \mathrm{~K}_{2} \mathrm{O}$ fed ${ }^{-1}$ rate resulted in values of the studied parameters e.g. sepals yield per feddan, dry weigh of sepals $\left(\right.$ gplant $\left.^{-1}\right)$, number of fruits plant $^{-1}$ and fresh weigh of fruits (gplant ${ }^{-1}$ ) amounted to (33.82 and 19.51\%), (39.03 and 21.21\%), (38.41 and $21.08 \%$ ) and (38.35 and $22.39 \%)$, respectively, lower than that with $48 \mathrm{~kg} \mathrm{~K}_{2} \mathrm{Ofed}^{-1}$ rate. The corresponding reduction values in $2^{\text {nd }}$ season were (34.53 and $\left.22.58 \%\right)$, (37.78 and $22.72 \%),(37.80$ and $22.42 \%)$ and (37.76 and $21.93 \%)$ in the same order of the treatments. The obtained results were in accordance with those reported by Abo-El-Seoud et al.(1994), Abdou et al.(2004), Abbas and Ali (2011) and Sakr et al.(2014).

Table 5: Sepals yield and its components of roselle plants as affected compost types and potassium fertilization rates and interaction in 2013 and 2014 seasons.

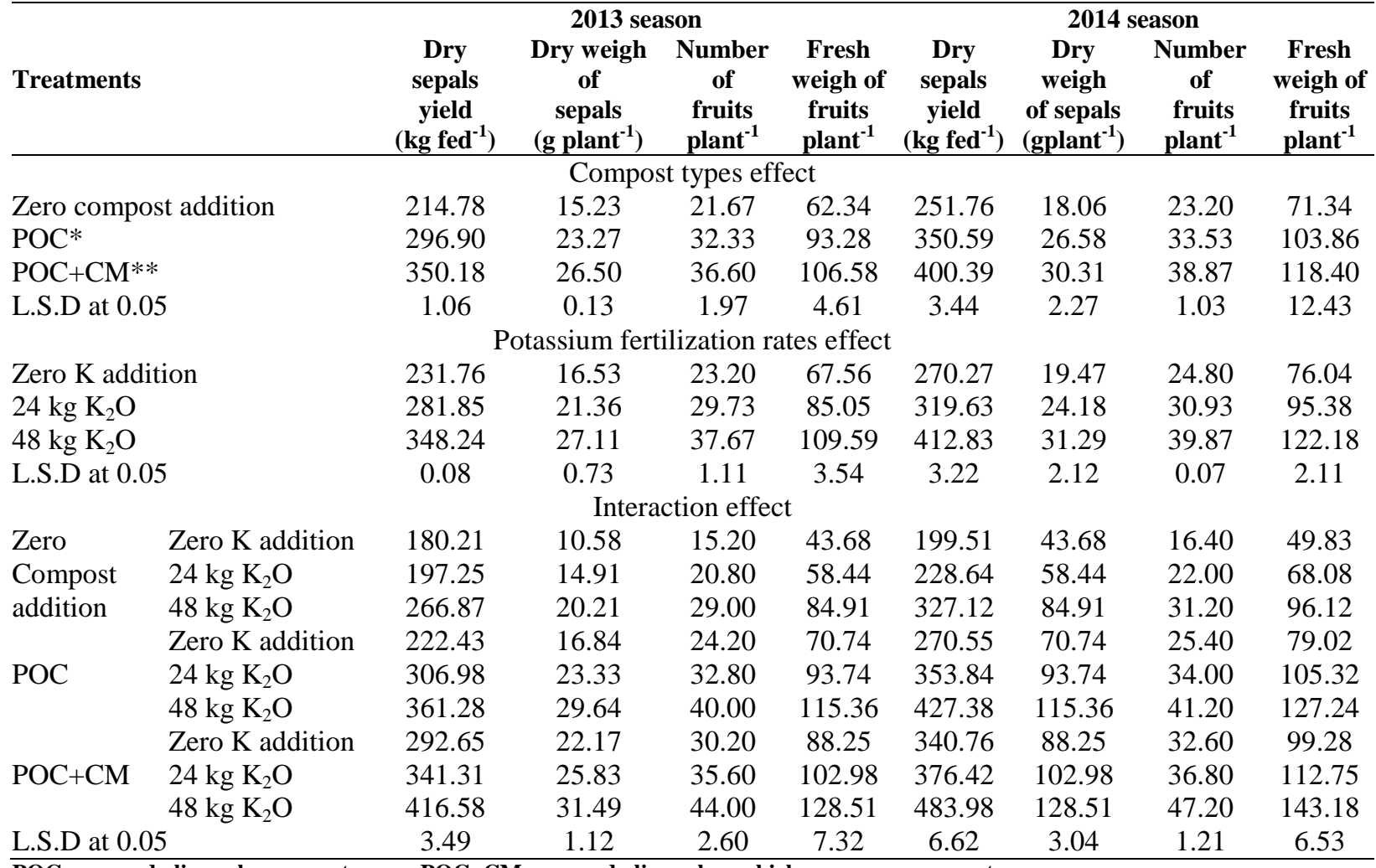

$\overline{\mathrm{POC}}=$ pressed olive cake compost

$\mathbf{P O C}+\mathrm{CM}=$ pressed olive cake + chicken manure compost

\section{(c) Effect of the interaction}

The interaction data indicated that $\mathrm{POC}+\mathrm{CM}$ compost as interacted with $\mathrm{K}$ fertilizer rate of $48 \mathrm{~kg}$ $\mathrm{K}_{2} \mathrm{O}$ exhibited the highest figures of the investigated parameters in $1^{\text {st }}$ and $2^{\text {nd }}$ season, Table 5.

3- Macronutrients ( $N, P$ and $K$ ) contents:

\section{(a) Effect of compost types}

Data in Table 6 reveal that the adopted compost types significantly affected $\mathrm{N}, \mathrm{P}$ and $\mathrm{K} \%$ of roselle petals, and the highest values were recorded with
POC+MC compost in $1^{\text {st }}$ and $2^{\text {nd }}$ seasons. The increases in $\mathrm{N}, \mathrm{P}$ and $\mathrm{K}$ contents, due to $\mathrm{POC}+\mathrm{CM}$ application, comprised (11.17 and 19.67\%), (29.55 and 54.05\%) and $(13.97$ and $22.95 \%)$ in $1^{\text {st }}$ season and (9.39 and $18.97 \%)$, (38.00 and $72.50 \%)$ and (16.07 and $23.81 \%)$ in $2^{\text {nd }}$ season, respectively, compared with POC and zero compost addition. Similar results were reported by Nabila and Aly (2002), El-Sheriff and Sarwat (2007), Gad (2011) and Abbas and Ali (2011) who stated that 
organic waste composts addition significantly increased N, P and K contents of Roselle dry matter.

(b) Effect of potassium fertilization rates

Data obtained in Table 6 show that the adopted potassium fertilization rates significantly influenced $\mathrm{N}$, $\mathrm{P}$ and $\mathrm{K} \%$ in sepals of Roselle plants in $1^{\text {st }}$ and $2^{\text {nd }}$ seasons, and the highest figures were reported with48 $\mathrm{kg} \mathrm{K}_{2} \mathrm{Ofed}^{-1}$ rate and reached to (2.07 and 2.26\%), $(0.51$ and $0.61 \%)$ and $(3.39$ and $3.69 \%)$ in $1^{\text {st }}$ and $2^{\text {nd }}$ seasons, respectively. With zero $\mathrm{K}$ addition and $24 \mathrm{~kg}$
$\mathrm{K}_{2} \mathrm{Ofed}^{-1}$ rate, $\mathrm{N}, \mathrm{P}$ and $\mathrm{K}$ contents tended to reduction by $(8.70$ and $3.38 \%),(27.45$ and $7.84 \%)$ and(18.66 and $12.26 \%)$ in $1^{\text {st }}$ season and in $2^{\text {nd }}$ seasons by $(10.62$ and $4.87 \%),(26.23$ and $13.11 \%)$ and(12.20 and 5.69\%), respectively, comparable with $24 \mathrm{~kg} \mathrm{~K}_{2} \mathrm{Ofed}^{-1}$ rate. The beneficial effects of potassium fertilizer on $\mathrm{N}, \mathrm{P}$ and $\mathrm{K} \%$ content were previously observed by Sakr et al. (2014) and Ghasemi et al. (2015) on Roselle plants.

Table 6: $\mathrm{N}, \mathrm{P}$ and $\mathrm{K}$ contents in sepal of Roselle plants as affected by compost types and Potassium fertilization rates and interaction in 2013 and 2014 seasons

\begin{tabular}{|c|c|c|c|c|c|c|c|}
\hline \multirow{2}{*}{\multicolumn{2}{|c|}{ Treatments }} & \multicolumn{3}{|c|}{2013 season } & \multicolumn{3}{|c|}{2014 season } \\
\hline & & $\mathrm{N \%}$ & $\mathbf{P \%}$ & $\mathrm{K} \%$ & $\mathrm{~N} \%$ & $\mathbf{P \%}$ & $\mathbf{K} \%$ \\
\hline \multicolumn{8}{|c|}{ Compost types effect } \\
\hline \multicolumn{2}{|c|}{ Zero compost addition } & 1.83 & 0.37 & 2.92 & 1.97 & 0.40 & 3.15 \\
\hline \multicolumn{2}{|c|}{ POC* } & 1.97 & 0.44 & 3.15 & 2.13 & 0.50 & 3.36 \\
\hline \multicolumn{2}{|c|}{$\mathrm{POC}+\mathrm{MC}^{* *}$} & 2.19 & 0.57 & 3.59 & 2.33 & 0.69 & 3.90 \\
\hline \multirow{2}{*}{\multicolumn{2}{|c|}{ L.S.D at 0.05}} & 0.15 & 0.60 & 0.21 & 0.11 & 0.04 & 0.13 \\
\hline & & Potassiur & izatiol & effect & & & \\
\hline \multicolumn{2}{|c|}{ Zero $\mathrm{K}$ addition } & 1.89 & 0.40 & 3.05 & 2.02 & 0.45 & 3.24 \\
\hline \multicolumn{2}{|l|}{$24 \mathrm{~kg} \mathrm{~K}_{2} \mathrm{O}$} & 2.00 & 0.47 & 3.23 & 2.15 & 0.53 & 3.48 \\
\hline \multicolumn{2}{|l|}{$48 \mathrm{~kg} \mathrm{~K}_{2} \mathrm{O}$} & 2.07 & 0.51 & 3.39 & 2.26 & 0.61 & 3.69 \\
\hline \multirow{2}{*}{\multicolumn{2}{|c|}{ L.S.D at 0.05}} & 0.10 & 0.05 & 0.11 & 0.09 & 0.04 & 0.09 \\
\hline & & \multicolumn{3}{|c|}{ Interaction } & & & \\
\hline Zero & Zero $\mathrm{K}$ addition & 1.74 & 0.30 & 2.74 & 1.89 & 0.32 & 2.91 \\
\hline Compost & $24 \mathrm{~kg} \mathrm{~K}_{2} \mathrm{O}$ & 1.83 & 0.38 & 2.92 & 1.94 & 0.41 & 3.18 \\
\hline \multirow[t]{2}{*}{ addition } & $48 \mathrm{~kg} \mathrm{~K}_{2} \mathrm{O}$ & 1.91 & 0.42 & 3.11 & 2.08 & 0.46 & 3.37 \\
\hline & Zero $\mathrm{K}$ addition & 1.86 & 0.38 & 2.97 & 2.00 & 0.42 & 3.21 \\
\hline \multirow[t]{3}{*}{ POC } & $24 \mathrm{~kg} \mathrm{~K} 2 \mathrm{O}$ & 1.97 & 0.44 & 3.16 & 2.15 & 0.49 & 3.29 \\
\hline & $48 \mathrm{~kg} \mathrm{~K}_{2} \mathrm{O}$ & 2.09 & 0.49 & 3.33 & 2.23 & 0.58 & 3.57 \\
\hline & Zero $\mathrm{K}$ addition & 2.07 & 0.51 & 3.44 & 2.18 & 0.60 & 3.59 \\
\hline \multirow[t]{2}{*}{$\mathrm{POC}+\mathrm{MC}$} & $24 \mathrm{~kg} \mathrm{~K}_{2} \mathrm{O}$ & 2.21 & 0.58 & 3.61 & 2.35 & 0.69 & 3.97 \\
\hline & $48 \mathrm{~kg} \mathrm{~K}_{2} \mathrm{O}$ & 2.29 & 0.63 & 3.73 & 2.46 & 0.78 & 4.13 \\
\hline \multicolumn{2}{|c|}{ L.S.D at 0.05} & NS & NS & NS & NS & NS & NS \\
\hline
\end{tabular}

(c) Effect of the interaction

Combination of compost types and $\mathrm{K}$ fertilization rates on $\mathrm{N}, \mathrm{P}$ and $\mathrm{K}$ percentages in sepal Roselle plants exhibited insignificant effects in $1^{\text {st }}$ and $2^{\text {nd }}$ seasons. However, the highest values were recorded with application of $\mathrm{POC}+\mathrm{MC}$ as interacted with the highest rates of $\mathrm{K}_{2} \mathrm{O}\left(48 \mathrm{~kg} \mathrm{fed}^{-1}\right)$. Meanwhile, the lowest values were recorded with compost and $\mathrm{K}$ fertilization - untreated plants in $1^{\text {st }}$ and $2^{\text {nd }}$ seasons. The obtained results are coincided with those reported by Montemurro et al. (2004) on rye-grass and Medjahdi et al. (2014) on durum wheat plants.

\section{4- Chemical constituents:}

\section{(a) Effect of compost types}

Data in Table 7 show that the studied chemical constituents of Roselle sepals, except $\mathrm{P}^{\mathrm{H}}$, significantly affected due to the tested compost types in $1^{\text {st }}$ and $2^{\text {nd }}$ seasons, and the highest figures were recorded with POC $+\mathrm{MC}$ compost addition. Values of chemical constituents e.g. total carbohydrates, anthocyanin content, ascorbic acid and $\mathrm{P}^{\mathrm{H}}$ seemed to reduce, under both without compost addition and POC, by (10.75 and 9.62\%), (12.05 and 5.13\%), (11.68 and 5.98\%) and (5.80 and $3.04 \%)$ in $1^{\text {st }}$ season, respectively, comparable with $\mathrm{POC}+\mathrm{MC}$. Whereas the corresponding reduction values in $2^{\text {nd }}$ season were (17.64 and $\left.10.39 \%\right),(12.14$ and $5.23 \%),(12.39$ and $6.94 \%)$ and $(5.15$ and $2.44 \%)$ in the same order of the treatments. These results are in good agreement with those found by Nabila and Aly (2002), El-Keltawi et al. (2003) and Postma et al. (2003) who indicated that organic waste composts significantly increased anthocyanin, total and soluble carbohydrates and ascorbic acid in Roselle sepals.

\section{(b) Effect of potassium fertilization rates}

The investigated chemical constituents of roselle sepals were significantly altered due to the adopted $\mathrm{K}$ fertilization rates, and the highest values of total carbohydrates, anthocyanin, ascorbic acid and $\mathrm{pH}$ were noticed with $48 \mathrm{~kg} \mathrm{~K}_{2} \mathrm{Ofed}^{-1}$ in $1^{\text {st }}$ and $2^{\text {nd }}$ seasons. Reducing $\mathrm{K}$ fertilization to be without $\mathrm{K}$ fertilization or 24 $\mathrm{kg} \mathrm{K}_{2} \mathrm{Ofed}^{-1}$ rate resulted in reductions in the abovementioned chemical constituents reached to $(6.43$ and $4.57 \%),(9.12$ and $4.31 \%),(5.19$ and $2.15 \%)$ and (3.91 and $1.68 \%$ ) in $1^{\text {st }}$ season, respectively, lower than those with48 $\mathrm{kg} \quad \mathrm{K}_{2} \mathrm{Ofed}^{-1}$ rate.The corresponding reduction values in $2^{\text {nd }}$ season were $(10.26$ and $5.66 \%)$, (10.96 and 6.24\%), (5.19 and 2.30\%) and (3.55 and $1.37 \%)$ in the same order of the treatments. These results come in agreement with Shalan et al. (2001) who found that applying potassium fertilizer at different rates 
increased anthocyanin and sugar contents of roselle sepals. Similar results obtained by Abbas and Ali (2011), Sakr et al. (2014) and Ghasemi et al. (2015) on Roselle.

(c) Effect of the interaction

Data in Table 7 prove that interaction of the adopted compost types and $\mathrm{K}$ fertilization rates insignificantly affected the studied chemical constituents of Roselle sepals. However, the highest values of total carbohydrate, anthocyanin, ascorbic acid and $\mathrm{pH}$ of Roselle sepals were recorded as POC $+\mathrm{MC}$ interacted with the highest rate of $\mathrm{K}$ fertilization (48 $\left.\mathrm{kgK}_{2} \mathrm{Ofed}^{-1}\right)$ in $1^{\text {st }}$ and $2^{\text {nd }}$ seasons.

Table 7: Total carbohydrates, anthocyanin, ascorbic acid contents and pH of Roselle sepals as affected by compost types and $K$ fertilization rates and interaction in 2012/2013 and 2013/2014 seasons

\begin{tabular}{|c|c|c|c|c|c|c|c|c|c|}
\hline \multirow[b]{2}{*}{ Treatments } & & \multicolumn{4}{|c|}{ 2012/2013 season } & \multicolumn{4}{|c|}{$2013 / 2014$ season } \\
\hline & & 氧 & 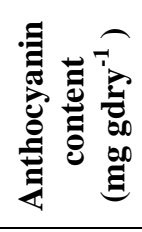 & 尝 & 풀 & 氧 & 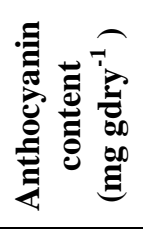 & 总 & 竞 \\
\hline \multicolumn{10}{|c|}{ Compost types effect } \\
\hline \multicolumn{2}{|c|}{ Zero compost addition } & 14.19 & 18.18 & 34.55 & 3.41 & 14.43 & 18.97 & 34.94 & 3.50 \\
\hline \multicolumn{2}{|c|}{ POC* } & 14.37 & 19.61 & 36.78 & 3.51 & 15.70 & 20.46 & 37.23 & 3.60 \\
\hline \multicolumn{2}{|l|}{$\mathrm{POC}+\mathrm{CM}^{* *}$} & 15.90 & 20.67 & 39.12 & 3.62 & 17.52 & 21.59 & 39.88 & 3.69 \\
\hline \multicolumn{2}{|l|}{ L.S.D at 0.05} & 0.11 & 0.27 & 0.80 & NS & 0.47 & 0.36 & 0.92 & $\mathrm{NS}$ \\
\hline \multicolumn{10}{|c|}{ Potassium fertilization rates effect } \\
\hline \multicolumn{2}{|c|}{ Zero $\mathrm{K}$ fertilizer addition } & 14.55 & 18.54 & 35.78 & 3.44 & 15.05 & 19.41 & 36.32 & 3.53 \\
\hline \multicolumn{2}{|l|}{$24 \mathrm{~kg} \mathrm{~K}_{2} \mathrm{O}$} & 14.84 & 19.52 & 36.93 & 3.52 & 15.82 & 20.44 & 37.43 & 3.61 \\
\hline \multicolumn{2}{|l|}{$48 \mathrm{~kg} \mathrm{~K}_{2} \mathrm{O}$} & 15.55 & 20.40 & 37.74 & 3.58 & 16.77 & 21.80 & 38.31 & 3.66 \\
\hline \multicolumn{2}{|l|}{ L.S.D at 0.05} & 0.22 & 0.71 & 0.41 & 0.21 & 0.61 & 0.83 & 0.45 & 0.06 \\
\hline \multicolumn{10}{|c|}{ Interaction } \\
\hline \multirow{3}{*}{$\begin{array}{l}\text { Zero compost } \\
\text { addition }\end{array}$} & Zero $\mathrm{K}$ addition & $13 . .21$ & 17.33 & 33.62 & 3.33 & 13.89 & 18.12 & 33.97 & 3.42 \\
\hline & $24 \mathrm{~kg} \mathrm{~K}_{2} \mathrm{O}$ & 13.87 & 18.15 & 34.78 & 3.42 & 14.27 & 18.87 & 35.12 & 3.51 \\
\hline & $48 \mathrm{~kg} \mathrm{~K}_{2} \mathrm{O}$ & 14.51 & 19.05 & 35.25 & 3.48 & 15.12 & 19.91 & 35.74 & 3.58 \\
\hline \multirow{4}{*}{ POC } & Zero $\mathrm{K}$ addition & 14.07 & 18.80 & 35.58 & 3.44 & 14.76 & 19.62 & 36.21 & 3.55 \\
\hline & $24 \mathrm{~kg} \mathrm{~K}_{2} \mathrm{O}$ & 14.68 & 19.76 & 36.92 & 3.51 & 15.62 & 20.68 & 37.34 & 3.61 \\
\hline & $48 \mathrm{~kg} \mathrm{~K}_{2} \mathrm{O}$ & 15.43 & 20.26 & 37.84 & 3.57 & 16.72 & 21.07 & 38.15 & 3.65 \\
\hline & Zero $\mathrm{K}$ addition & 15.02 & 19.48 & 38.15 & 3.55 & 16.51 & 20.48 & 38.77 & 3.63 \\
\hline \multirow{2}{*}{$\mathrm{POC}+\mathrm{MC}$} & $24 \mathrm{~kg} \mathrm{~K}_{2} \mathrm{O}$ & 15.96 & 20.65 & 39.08 & 3.64 & 17.58 & 21.77 & 39.83 & 3.70 \\
\hline & $48 \mathrm{~kg} \mathrm{~K}_{2} \mathrm{O}$ & 16.71 & 21.88 & 40.13 & 3.68 & 18.47 & 22.53 & 41.05 & 3.75 \\
\hline \multicolumn{2}{|l|}{ L.S.D at 0.05} & NS & NS & NS & NS & NS & NS & NS & $\mathrm{NS}$ \\
\hline
\end{tabular}

\section{CONCLUSION}

Under the conditions of the present study, it is advisable to apply pressed olive cake compost due to its beneficial effect in improving Roselle sepals production and quality. In addition, applying compost of pressed olive cake + chicken manure combined with $\mathrm{K}$ fertilization at $48 \mathrm{~kg} \mathrm{~K} \mathrm{~K}_{2} \mathrm{O} \mathrm{fed}^{-1}$ rate was superior to achieve the highest figures in this concern.

\section{REFERENCES}

Abbas, M.K. and A.S. Ali (2011). Effect of foliar application of NPK on some growth characters of two cultivars of roselle (Hibiscus sabdariffa). American J. Plant Physiol., 6 (4): 220-227.

Abdou, M.A.H.; M.A. El-Sayed; F.S. Badran R.S. and El-Deen (2004). Effect of planting density and chemical and biofertilization on vegetative growth, yield and chemical composition of fennel (Foeniculum vulgare, Miller): II-Effect of NPK chemical fertilization and biofertilization treatments. Annals of Agricultural Science, 42 (4): 1923-1937.
Abo-EI-Seoud M.A., M.F. Hashim and F.A. Mohamed (1994). Combined effect of gamma radiation and potassium fertilization on growth and coloring matter contents of Roselle (Hibiscus Sabdariffa L.). Second Arab Conference on the Peaceful Uses of Atomic Energy, Cairo, p.p: 863-874.

Abo-El-Seoud, M.A.A.; M.F. abdel-Sabour and E.A. Omar (1997). Productivity of roselle (Hibiscus sabdariffa L.) plant as affected by organic waste composts addition to sandy soil. Bull. Natl. Res. Center, Cairo, 22: 495-505.

Adanlawo I.G. and V. A. Ajibade (2006). Nutritive value of the two varieties of roselle (Hibiscus sabdariffa) calyces soaked with wood ash. Pak. J. Nutr. 5, 555- 557.

Ahmed, S.K.; E.O. El-Ghawas and A.F. Aly (1998). Effect of dry yeast and organic manure on roselle plant. Egypt. J. Agric. Research, 76: 1115-1142.

Ammar E. and B. Ben Rouina (1999). Potential horticultural utilization of olive oil processing wastewater. Acta Horto. 4 (74):741-744. 
AOAC (1975). Association of Agricultural Chemist, Washington, D.C., 200. Official Method of Analysis $12^{\text {th. }}$ Ed., 44: 94-117.

Ben-Jenana R.K.; M.A. Triki; R. Haoula; C. Hanachi; M. Ben Khedher and A.B. Henchi (2009). Composted posidonia, chicken manure and olive mill residues an alternative to peat as seed germination and seedling growing media in Tunisian Nursy. Pakistan J. Bot. 41(6): 3139 3147.

Bidari, B.I.and N.S. Hebsur (2011) Potassium in relation to yield and quality of selected vegetable crops. Karnataka J. Agric. Sci., 24 (1): 55-59.

Black, C.A. (1982) Methods of Soil Analysis." Amer. Sec. Agron. Inc. Publisher. Madison, Wisconsin, U S A.

Byamukama R.; M.Andima; A. Mbabazi and B.T. Kiremire (2014). Anthocyanins from mulberry (Morusrubra) fruits as potential natural colour additives in yoghurt. African Journal of Pure and Applied Chemistry. 8 (12): 182-190.

Cucci, G.; G. Lacolla and L. Caranfa (2008). Improvement of soil properties by application of olive oil waste. Agron. Sustain. Dev. 28:521-526.

El-Keltawi, N.E.; A.A. Tawfik and A.M. Ahmed (2003). Roselle (Hibiscus sabdariffa L.) production as affected by two natural alternatives to farmyard manure: П- chemical assessment of sepal quality. Assuit. J. of Agric. Sci., 34 (6): 307-321.

El-Sheriff, M.H. and M.E. Sarwat (2007). Physiological and chemical variations in producing roselle plant (Hibiscus Sabdariffa. L.) by using organic farmyard manure. World J. Agric., Sci., 3 (5): 609-616.

El-Tantawy, M.E. and M.A.N. Mohamed (2009). Effect of inoculation with phosphate solubilizing bacteria on the tomato rhizosphere colonization process, plant growth and yield under organic and inorganic fertilization. Journal of Applied Sciences Research, 5(9): 1117-1131.

Faraji, M.H. and A. H. Tarkhni (1999).The effect of sour tea (Hibiscus sabdariffa) on essential hypertension. J. of Ethnopharmacology, 7: 231-236.

Gad, N. (2011). Productivity of roselle (Hibiscus sabdariffa L.) plant as affected by cobalt and organic Fertilizers. J. Appl. Sci. Res., 7(12): 1785-1792

Ghasemi, S.; K. Abbaszadeh; M. Ghasemi; M. Salari; F. Zarei (2015). Effect of application of nitrogen and potassium fertilizers on some vegetative and reproductive traits in Roselle (Hibiscus sabdariffa). International Journal of Agronomy and Agricultural Research, 7(2): 75-79.

Giovanna, C.;L. Giovanni and C. Leonardo (2008) Improvement of soil properties by application of olive oil waste. Agron. Sustain. Dev. 28: 521-526.

Hachicha, S.; M. Chtourou; K. Medhioub and E. Ammar (2006). Compost of poultry manure and olive mill wastes as an alternative fertilizer. Agron. Sustain. Dev. 26:135-142.
Medjahdi, N.; A.D. Djbeura and M. Kaid-Harache (2014). Effect of three types of composts of olive by products on growth and yield of hard wheat 'Triticum durum Desf'. Afr. J. Biotchnol. 13(52): 4685-4693.

Montemurro, F.; G. Convertini and D. Ferri (2004). Mill wastewater and olive pomace compost as amendments for rye-grass. Agronomie, Sciences, 24 (8):481-486.

Nabila, Y.N. and M.S. Aly (2002). Variations in productivity of (Hibiscus sabdariffa L.) in response to some agricultural supplementation. Annals of Agric. Sci. (Cairo), Faculty of Agric. Ain Shams Univ. Cairo, Egypt, 47 (3): 875-892.

Nielsen, S.S. (2010). Food Analysis and Laboratory Manual. Second Edition. Purdue University West Lafayette, IN, USA.

Parkinson, J. A. and S. E. Allen (1975). A wet oxidation procedure suitable for the determination of nitrogen and mineral nutrients in biological material. Communications in Soil Science and Plant Analysis, 6 (1): 1-11.

Parr, J.F., and S.B. Hornick. (1992). Agricultural use of organic amendments: A historical perspective. Am. J. Alternative Agric. 7:181-189.

Postoma , J.; M. Montanari; P.Vanden and H.J.F. Boogert (2003). Microbial enrichment to enhance the disease suppressive activity of compst. Euro. J. Soil Biol., 39: 157-163.

Riad, A. (1982). Potential sources of organic matter in Egypt. FAO soil Bull., 45: 22-25.

Ryan, J.; S. Garabet; K. Harmsen and A. Rashid (1996). Soil and Plant Analysis. Manual Adapted for the west Asia and North Africa Region. ICARDA, Aleppo, Syria. 140 pp.

Sakr, W.R.A; H.M. Elbagoury;M.A. Sidky; S.A. Ali (2014). Production of organic roselle by natural minerals and biofertilizers. American-Eurasian J. Agric. \& Environ. Sci. 14(10), 985-995.

Sellami, F.; R. Hachicha; K. Meddich and E. ammer (2007). Composting of oil exhausted olive-cake, poultry manure and industrial residues of agrofood activity for soil amendment. Bioresour. Tecnol. 99:1177-1188.

Shalan, M.N.; T.A. Abd El-Latif; S.G. Soliman and E.O. El-Gawwas (2001). Effect of some chemical and biofertilizer treatments on roselle plants (Hibiscus sabdariffa L.). Egyptian Journal of Agricultural Research, 79 (2): 587- 606.

Snedecor, G.W. and W.G. Cochran (1980). One way classification-Analysis of Variance - The random effect model- Two way Classification (Eds) In Statistical Methods. The Iowa State Univ. Press, Amer. Iowa, USA, 215-273.

Tomar, O.S.; P.S.Minhas; V.K.Sharma; Y.P. Singh and R.K. Gupta (2003). Performance of 31 tree species and soil conditions in a plantation established with saline irrigation. Forest Ecology and Management, 177 (2003) 333-346. 
Tomati, U., E. Galli, F. Fiorelli and L. Pasetti (1996). Fertilizers from composting of olive-mill wastewaters. International Biodeterioration and Biodegradation, 38:155-162.
Yasser, M.A.; E. A. Shalaby and N.T. Shanan (2011). The use of organic and inorganic cultures in improving vegetative growth, yield characters and antioxidant activity of roselle plants (Hibiscus sabdariffa L.). African Journal of Biotechnology 10 (11): 1988-1996.

استجابة نباتات الكركدية لإضافة نوعين من كمبوست المتبقي من استخلاص زيت الزيتون ومستويات مختلفة من

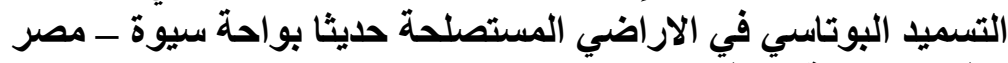
خطاب عبد الباقي خطاب في الإن معهد بحوث الأباضي والمباه والبيئة - مركز البحوث الزراعية

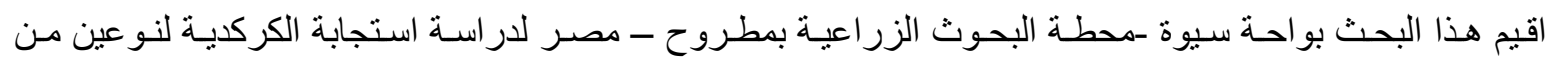

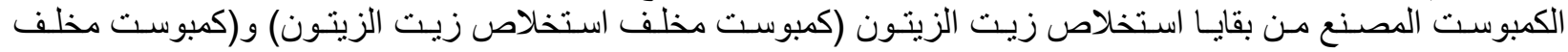

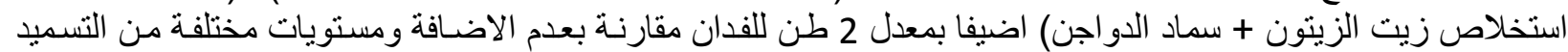

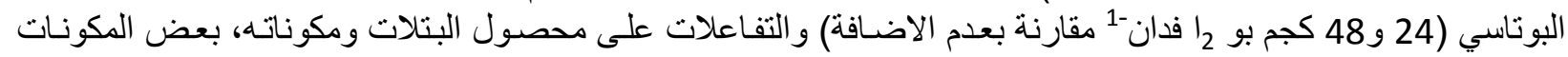

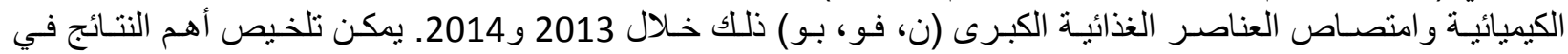

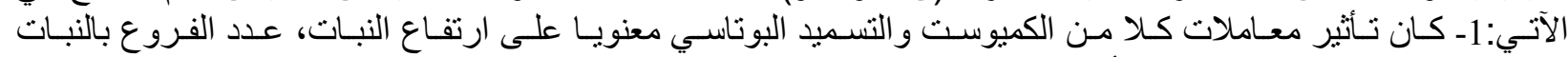

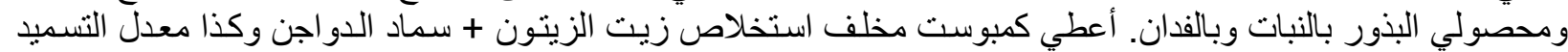

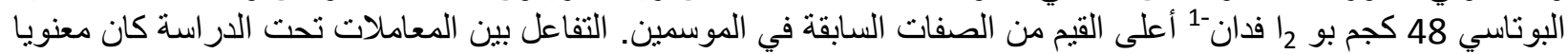

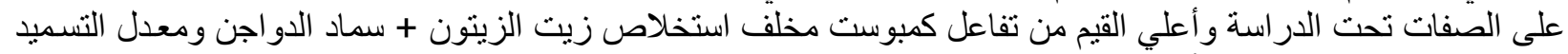

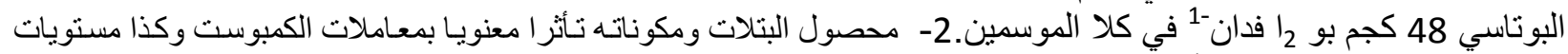

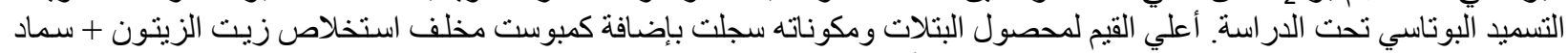

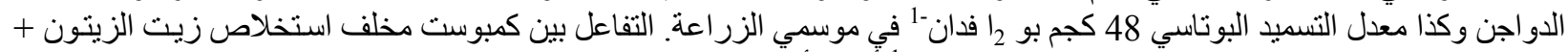

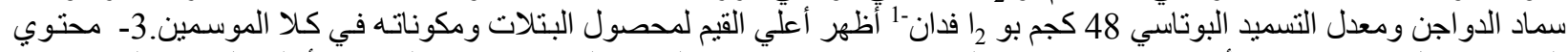

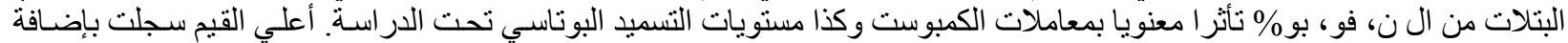

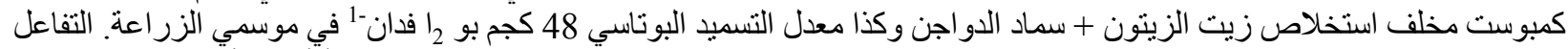

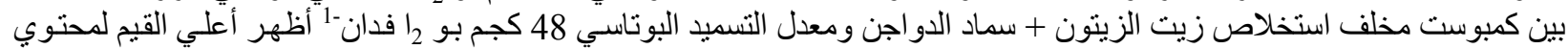

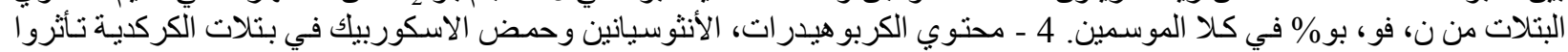

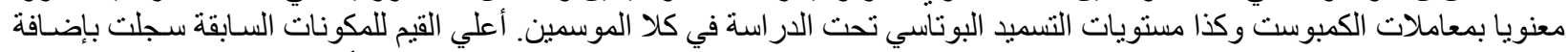

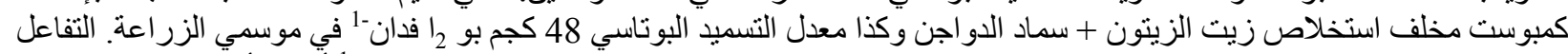

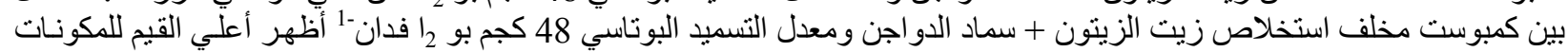

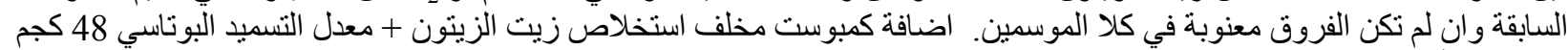

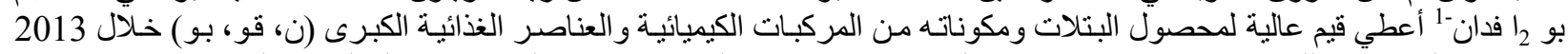

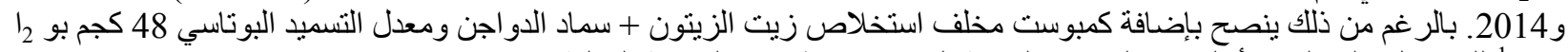
فدان-1 للحصول على القيم الأعلى من الصفات السابقة الذكر تحت ظروف التجربة التبرة الحالية. 